\title{
Feeding habit of Eigenmannia trilineata Lopez \& Castello, 1966 (Teleostei: Sternopygidae) of Parque Estadual de Itapuã, RS, Brazil
}

\author{
Júlia Giora, Clarice B. Fialho and Ana Paula S. Dufech
}

This study aims to describe the feeding habits of a population of the weakly electric fish Eigenmannia trilineata from Southern Brazil through the monthly frequency variation of replection (RI) and hepatosomatic (HSI) indexes, condition factor (CF) and dietary analysis of the species, besides the comparison of the results with abiotic factors. We collected 428 specimens from June/2002 to May/2003 with a dip net and electric fish detector. Stomach contents were analyzed using three measurements: frequency of occurrence of food items, percentage composition per prey type and feeding importance index. Microcrustacea and autochthonous insects were the dominant food items in the stomachs of E. trilineata. The adults (males larger than 63.5 $\mathrm{mm}$ and females larger than $80.5 \mathrm{~mm}$ ) exhibited little alteration in their diet during the reproductive period and ingested more variety of food items. The RI of males, but not females, showed peaks before and after the reproductive period, having significant correlation with the HSI. Condition factor was more influenced by stomach weight in males and by the gonad weight in females. No correlation between abiotic factors and feeding activity was identified.

Este estudo objetiva descrever o hábito alimentar de uma população da espécie de peixe elétrico Eigenmannia trilineata do Sul do Brasil, através da variação das freqüências mensais dos índices de repleção (IR), hepatossomático (IHS), fator de condição (FC) e análise da dieta da espécie, além da comparação dos resultados obtidos com fatores abióticos. Foram coletados 428 exemplares entre os meses de junho/2002 e maio/2003 com o auxílio de rede do tipo puçá e um detector de peixe elétrico. Os conteúdos estomacais foram analisados utilizando três métodos de mensuração: freqüência de ocorrência de itens alimentares, composição percentual por tipo de presa e índice de importância alimentar. E. trilineata apresentou microcrustáceos e insetos autóctones como alimentos principais. Os adultos (machos maiores que $63,5 \mathrm{~mm}$ e fêmeas maiores que $80,5 \mathrm{~mm}$ ) tiveram pequena alteração em sua dieta durante o período reprodutivo e ingeriram uma maior variedade de itens do que os juvenis. $\mathrm{O}$ IR dos machos apresentou picos antes e depois do período reprodutivo, obtendo correlação significativa com o IHS, fato este não verificado para as fêmeas. $\mathrm{O}$ fator de condição foi mais influenciado pelo peso do estômago nos machos e das gônadas nas fêmeas. Não foi identificada correlação entre fatores abióticos e a atividade alimentar da espécie.

Key words: Gymnotiformes, electric-fish, diet, southern Brazil.

\section{Introduction}

The order Gymnotiformes is restricted to Neotropical freshwater, occurring from Guatemala to Argentina, and also on the Caribbean island of Trinidad (Mago-Leccia, 1976). These South American electric fishes are a very successful group, being found in all kinds of aquatic habitat, including river channels, flood-plains, flooded forests, forest streams, cataracts, swamps, coastal creeks and estuarine reaches (Crampton, 1998).

The Family Sternopygidae are known from the continental waters of all South American countries except Chile, ranging from the La Plata River of Argentina to the Tuira River of Panama (Albert, 2001). The ecology and natural history of most sternopygid species is very poorly understood (Albert, 2003).

Few studies about diet and feeding habits of gymnotiform electric fishes are available. Barbieri \& Barbieri (1984) described the nutritional dynamic of Gymnotus carapo of the family Gymnotidae, from the Lobo dam, São Paulo, Brazil. Other gymnotiforms are quoted in studies of the trophic structure of fish communities in different localities of Brazil (Soares, 1979; Mérigoux \& Ponton, 1998; Hahn et al., 1997; Agostinho et al., 2003; Alves-Gomes, 1997).

This study aims to describe the diet of an Eigenmannia trilineata population from lagoa Negra, Parque Estadual de Itapuã, Rio Grande do Sul state, Brazil, to compare juvenile and adult feeding habits, and test possible relations between

Laboratório de Ictiologia, Departamento de Zoologia, Programa de Pós-Graduação em Biologia Animal, Universidade Federal do Rio Grande do Sul. Av. Bento Gonçalves, 9500, Prédio 43435, 90540-000 Porto Alegre, RS, Brazil. e-mail: jugiora@hotmail.com 
the feeding activity and abiotic factors such as temperature, rainfall and photoperiod. The species Eigenmannia trilineata is known to occur in the Paraná and Paraguay river basins of Brazil, Argentina, Paraguay and Uruguay (Albert, 2003), but we herein additionally recognize this species as occurring in the Laguna dos Patos drainage

\section{Material and Methods}

Study area. The Parque Estadual de Itapuã, in the Southern Brazilian state of Rio Grande do Sul, is a state park with an area of $55.66 \mathrm{~km}^{2}$. It represents the last preserved ecosystem unit in the Porto Alegre metropolitan region, and includes grassland, dunes, lakes, islands, beaches and forested hills along the margins of the lago Guaíba and laguna dos Patos.

Lagoa Negra covers $17.5 \mathrm{~km}^{2}$ and is separated from laguna dos Patos by sand dunes almost completely covered with bushes and herbs. The lagoa Negra west margin, opposite to the laguna dos Patos, consists of an area used to raise cattle, with abandoned irrigation channels for rice cultivation and some areas of Eucalyptus plantation.

The collection site was located in an abandoned rice irrigation channel flowing into lagoa Negra's west margin. The water has low transparency due to the large amount of organic matter in suspension, low acidity, a muddy bottom and an average depth of $1 \mathrm{~m}$. There was a predominance of aquatic macrophytes, with $E$. trilineata often being encountered in the root mats of Pistia stratiotis, Salvinia auriculata, and roots of Poligonum sp.

Sampling. Collections were made monthly from June 2002 until May 2003 (but bimonthlyh between October 2002 and February 2003), in order to monitor the reproductive seasonality of E. trilineata and assess possible influences on feeding dynamics. Specimens were collected between 11:00 a.m. and 12:30 p.m. using a dip net under floating vegetation and an electric fish detector, which is an audio-amplifier connected to electrodes mounted on the end of a pole.

The specimens were fixed in the field in $10 \%$ formalin solution. Temperatures of water and air were registered at the time of collection. Rainfall data were obtained at the Meteorology District of Porto Alegre. Sunrise and sunset times and photoperiod were obtained with the program Skymap.

In the laboratory, fishes were transferred to $70 \%$ ethanol and after that total length (Lt) in millimeter and total weight $(\mathrm{Wt})$ in grams were measured. Individuals were dissected to register liver (Wl) and stomach (Ws) weight in grams, and intestine length ( $\mathrm{Li})$ in millimeters. Voucher specimens were catalogued in the fish collection of the Departamento de Zoologia, Universidade Federal do Rio Grande do Sul, Porto Alegre, Brazil (lots UFRGS 5719 and UFRGS 6635).

Data analysis. Stomach repletion index (RI) and hepatosomatic index (HsI) were estimated following the adapted formula from Santos (1978). These indexes represent the percentile organ weight related to the fish total weight: $\mathrm{RI}=\mathrm{Ws} \times 100 / \mathrm{Wt}$; and
$\mathrm{HsI}=\mathrm{Wl} \times 100 / \mathrm{Wt}$; where Ws corresponds to the stomach weight, Wl to the liver weight and Wt to the total weight. The Spearman's non-parametric test was used to verify possible correlations between RI and HsI.

The condition factor (CF) was estimated by the association of weight and length: $\mathrm{CF}=\left(\mathrm{Wt} / \mathrm{Lt} \mathrm{t}^{\mathrm{q}}\right) \times 100$.

Mean monthly values of the condition factor were determined with these estimated values. CF was corrected by the following expressions to verify the influence of gonad and stomach weight in this condition factor variation: $\mathrm{CF} 1=[(\mathrm{Wt}$ $\left.-\mathrm{Wg}) / \mathrm{Lt}^{\mathrm{t}}\right] \times 100$; and CF2 $=\left[(\mathrm{Wt}+\mathrm{Ws}) / \mathrm{Lt}^{\mathrm{q}}\right] \times 100$. Differences between $\mathrm{CF}-\mathrm{CF} 1=\Delta \mathrm{CFI}$ (gonad influence $)$ and CF1 $\mathrm{CF} 2=\Delta \mathrm{CFII}$ (stomach influence) were calculated.

The intestinal quotient (IQ) represents the ratio of the intestine length related to the total length. IQ is calculated by: $\mathrm{IQ}=\mathrm{Li} / \mathrm{Lt}$; $\mathrm{Li}$ corresponds to the intestine length and $\mathrm{Lt}$ to the total length.

Multiple regression with analysis of variance (ANOVA) was applied to verify possible dependence between the rainfall, photoperiod and temperature abiotic factors and the feeding activity (Zar, 1999).

Stomach content analysis was performed with the help of a stereomicroscope and the organisms in the stomach contents were identified to the lowest possible taxonomic level. The alimentary items were analyzed by the frequency of occurrence method (Hyslop, 1980) and by percent composition method (Hynes, 1950), where the number of times that each item has occurred is treated as the percent of the total number of occurrences of all items. To accomplish that, the items were grouped in ample taxonomic and ecological categories: Microcrustacea (Microcr), digested organic material (DOM), autochthonous insects (AuI), allochthonous insects (AlI), Arachnida (Arac), plant material (PM), sediment (Sed), and other (Other).

The importance of each of these alimentary categories in the diet of the species was estimated by a semi-quantitative abundance scale, where each category contribution is estimated according to the area that it occupies in relation to total content. The scale used was based on Granado-Lorencio \& Garcia-Novo (1986): 0 - absent; 1 - scarce (less than 25\%); 2 - frequent ( $25 \%$ to less than $50 \%) ; 3$ - very frequent $(50 \%$ to less than $75 \%$ ); 4 - abundant (75\% to $100 \%$ ). From this scale the index of alimentary importance (IAI) was calculated from the formula (Granado-Lorencio \& Garcia-Novo, 1986): $\mathrm{IAI}=\mathrm{S}\left[\left(\mathrm{X}_{\mathrm{K}} \cdot \mathrm{k}\right) /(\mathrm{n}-1)\right]$; where $\mathrm{X}_{\mathrm{K}}$ equals the frequency of occurrence of a certain diet component $\mathrm{X}_{\mathrm{i}}$, with category $\mathrm{k}$; $\mathrm{K}$ is the abundance category $(0,1,2,3$ and 4$)$, and $\mathrm{n}$ is the number of categories of the scale.

According to Guillen \& Granado (1984), main food is that which presents IAI values above 0.3 ; additional food from 0.3 to 0.15 , and accidental food presents values below 0.15 . Data were evaluated monthly.

Comparisons were made between juvenile and adult diets. Males with total length exceeding $63.5 \mathrm{~mm}$ and females with total length exceeding $80.5 \mathrm{~mm}$ were considered adults. These measurements correspond to the first gonadal maturation size (Giora pers. obs.). 
Table 1. Frequency of occurrence of identified food items for E. trilineata adults ( $*=$ allochthonous origin).

\begin{tabular}{|c|c|c|c|c|c|c|c|c|c|c|c|c|}
\hline Alimentary Items & Jun & Jul & Aug & Sep & Oct & Nov & Dec & Jan & Feb & Mar & Apr & May \\
\hline Crustacea & 100 & 100 & 100 & 100 & 96.77 & 96.3 & 100 & 86.67 & 100 & 100 & 100 & 100 \\
\hline Decapoda & 0 & 0 & 0 & 0 & 0 & 0 & 0 & 3.33 & 0 & 0 & 0 & 0 \\
\hline Microcrustacea & 100 & 100 & 100 & 100 & 96.77 & 96.3 & 100 & 86.67 & 100 & 100 & 100 & 100 \\
\hline Cladocera & 95.45 & 100 & 96.43 & 100 & 93.55 & 66.67 & 74.29 & 43.33 & 55.17 & 88 & 96 & 100 \\
\hline Copepoda & 81.82 & 100 & 89.28 & 96.15 & 96.77 & 96.3 & 97.14 & 86.67 & 93.1 & 96 & 100 & 100 \\
\hline Ostracoda & 90.91 & 62.5 & 67.86 & 65.38 & 6.45 & 14.81 & 17.14 & 36.67 & 34.48 & 72 & 52 & 25.81 \\
\hline Insecta & 90.91 & 100 & 100 & 100 & 100 & 100 & 100 & 96.67 & 100 & 100 & 100 & 100 \\
\hline Diptera & 68.18 & 100 & 89.28 & 96.15 & 90.32 & 92.59 & 94.29 & 83.33 & 89.66 & 100 & 92 & 100 \\
\hline Brachycera* & 0 & 12.5 & 0 & 3.85 & 3.23 & 0 & 0 & 3.33 & 0 & 0 & 0 & 0 \\
\hline Chironomidae (larvae) & 68.18 & 100 & 89.28 & 96.15 & 90.32 & 92.59 & 94.29 & 83.33 & 89.66 & 100 & 92 & 100 \\
\hline Chironomidae (pupae) & 0 & 12.5 & 0 & 38.46 & 16.13 & 11.11 & 20 & 6.67 & 0 & 4 & 4 & 25.81 \\
\hline Hymenoptera* & 22.73 & 18.78 & 3.57 & 15.38 & 0 & 0 & 2.86 & 10 & 0 & 4 & 0 & 0 \\
\hline Formicidae* & 22.73 & 18.75 & 3.57 & 15.38 & 0 & 0 & 2.86 & 10 & 0 & 4 & 0 & 0 \\
\hline Ephemeroptera (nymph) & 9.09 & 43.75 & 14.28 & 88.46 & 61.29 & 70.37 & 57.14 & 13.33 & 13.79 & 32 & 36 & 61.29 \\
\hline Ephemeroptera (larvae) & 0 & 0 & 0 & 0 & 0 & 3.7 & 0 & 0 & 13.79 & 4 & 0 & 3.23 \\
\hline Coleoptera (adult)* & 0 & 6.25 & 0 & 0 & 0 & 0 & 0 & 0 & 0 & 0 & 0 & 0 \\
\hline Coleoptera (larvae) & 0 & 0 & 3.57 & 3.85 & 6.45 & 0 & 8.57 & 6.67 & 0 & 0 & 0 & 12.9 \\
\hline Odonata (nymph) & 0 & 6.25 & 14.28 & 19.23 & 12.9 & 25.93 & 37.14 & 6.67 & 13.79 & 8 & 16 & 3.23 \\
\hline Trichoptera & 0 & 0 & 0 & 42.31 & 35.48 & 37.04 & 48.57 & 66.67 & 89.66 & 100 & 96 & 96.77 \\
\hline Lepidoptera (larvae)* & 0 & 6.25 & 7.14 & 0 & 3.23 & 11.11 & 25.71 & 16.67 & 24.14 & 20 & 20 & 19.35 \\
\hline Hemiptera & 0 & 12.5 & 7.14 & 30.77 & 32.26 & 7.41 & 11.43 & 0 & 3.45 & 0 & 0 & 0 \\
\hline Heteroptera & 0 & 6.25 & 7.14 & 30.77 & 32.26 & 7.41 & 11.43 & 0 & 3.45 & 0 & 0 & 0 \\
\hline Auchenorrhyncha* & 0 & 6.25 & 0 & 0 & 0 & 0 & 0 & 0 & 0 & 0 & 0 & 0 \\
\hline Isoptera* & 0 & 0 & 0 & 0 & 3.23 & 0 & 0 & 0 & 0 & 0 & 0 & 0 \\
\hline Insects parts & 54.54 & 93.75 & 82.14 & 92.31 & 83.87 & 77.78 & 88.57 & 60 & 44.83 & 56 & 60 & 29.03 \\
\hline Aracnida & 0 & 0 & 21.43 & 23.08 & 51.61 & 33.33 & 37.14 & 43.33 & 31.03 & 28 & 16 & 35.48 \\
\hline Acarina & 0 & 0 & 21.43 & 23.08 & 51.61 & 33.33 & 37.14 & 40 & 31.03 & 28 & 16 & 35.48 \\
\hline Aranae & 0 & 0 & 0 & 0 & 0 & 0 & 0 & 6.67 & 3.45 & 0 & 0 & 0 \\
\hline Mollusc Gastropodo & 0 & 0 & 0 & 0 & 0 & 0 & 2.86 & 0 & 3.45 & 0 & 0 & 0 \\
\hline Fish oocyte & 13.64 & 0 & 0 & 0 & 3.23 & 11.11 & 5.71 & 20 & 3.45 & 0 & 0 & 0 \\
\hline Scale & 9.09 & 6.25 & 0 & 0 & 0 & 3.7 & 0 & 0 & 0 & 0 & 0 & 0 \\
\hline Spicule & 4.54 & 0 & 0 & 0 & 0 & 0 & 0 & 0 & 0 & 0 & 0 & 0 \\
\hline Organic Material & 100 & 100 & 100 & 100 & 100 & 100 & 100 & 100 & 100 & 100 & 96 & 100 \\
\hline Plant Material & 100 & 93.75 & 82.14 & 76.92 & 77.42 & 92.59 & 100 & 90 & 89.66 & 96 & 92 & 96.77 \\
\hline Sediment & 22.73 & 37.5 & 42.86 & 46.15 & 58.06 & 88.89 & 94.29 & 93.33 & 89.66 & 92 & 92 & 90.32 \\
\hline $\mathrm{n}$ & 22 & 16 & 28 & 26 & 31 & 27 & 35 & 30 & 29 & 25 & 25 & 31 \\
\hline
\end{tabular}

\section{Results}

During this work 428 specimens of $E$. trilineata were collected: 209 males (total length $35.29 \mathrm{~mm}-247.79 \mathrm{~mm}$ ), 195 females $(34.76 \mathrm{~mm}-170 \mathrm{~mm})$ and 24 larvae $(16.95 \mathrm{~mm}-32.02$ mm) (Nakatani et al., 2001).

A total of 28 food items were found in adult stomachs the most frequent being: Microcrustacea (Cladocera, Copepoda, Ostracoda), chironomid larvae, non-identified insect parts, digested organic material, plant material and sediment (Table 1). Only 17 items were found in juvenile stomachs the most frequent being: Microcrustacea (Cladocera, Copepoda, Ostracoda), chironomid larvae, digested organic material, plant material and sediment (Table 2).

The percent composition was calculated for all the individuals, without adult and juvenile separation, with the purpose of presenting a general view of ingested item categories for the species. The most represented categories were DOM, Microcr and AuI, followed by PM and Sed. Arac, AlI and Other had a minor apperance in the diet composition (Fig. 1).

The index of alimentary importance (IAI) was calculated separately in adults and juveniles (Tables 3 and 4). Microcrustacea was a main food item for juveniles during all months, and from main to additional item for adults. DOM constituted a main item for both juveniles and adults through- out the year. PM represented an additional food item for juveniles and adults during almost all months. AuI varied monthly from main to additional item in juveniles and represented an accidental food item only in one month. The same food category constituted a main food item in almost all months for adults. The occurrence of Sed in stomach contents had a very similar distribution in both juveniles and adults, being classified as an additional or accidental food item. AlI, Arac and Other were absent or accidental food items for adults and juveniles.

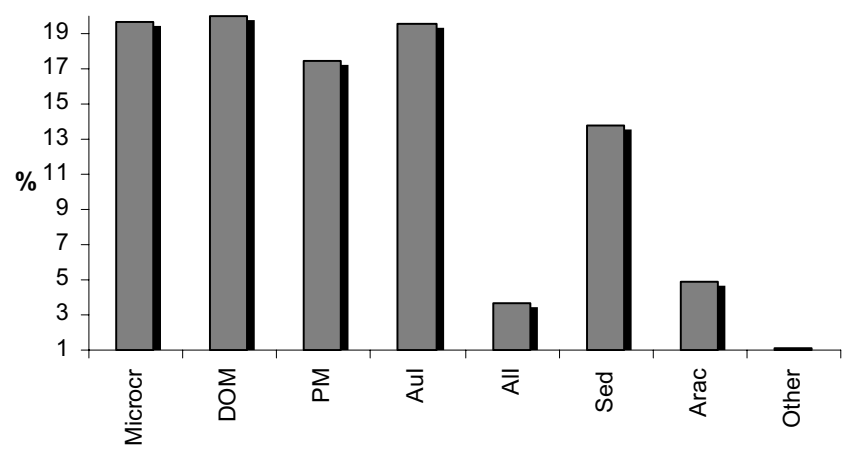

Fig. 1. Percent composition of Eigenmannia trilineata alimentary items calculated for both adult and juveniles. 
Table 2. Frequency of occurrence of identified food items for E. trilineata juveniles ( ${ }^{*}=$ allochthonous origin).

\begin{tabular}{|c|c|c|c|c|c|c|c|c|c|c|c|c|}
\hline Alimentary Items & Jun & Jul & Aug & Sep & Oct & Nov & Dec & Jan & Feb & Mar & Apr & May \\
\hline Crustacea & 100 & 100 & 75 & 100 & 100 & 100 & 100 & 100 & 100 & 100 & 100 & 100 \\
\hline Microcrustacea & 100 & 100 & 75 & 100 & 100 & 100 & 100 & 100 & 100 & 100 & 100 & 100 \\
\hline Cladocera & 100 & 100 & 75 & 100 & 100 & 83.33 & 100 & 66.67 & 62.5 & 100 & 100 & 50 \\
\hline Copepoda & 72.73 & 93.75 & 75 & 100 & 100 & 100 & 100 & 100 & 100 & 100 & 100 & 100 \\
\hline Ostracoda & 81.82 & 31.25 & 50 & 12.5 & 22.22 & 0 & 0 & 33.33 & 12.5 & 66.67 & 0 & 0 \\
\hline Insecta & 100 & 81.25 & 75 & 100 & 100 & 100 & 50 & 100 & 100 & 100 & 100 & 100 \\
\hline Diptera & 90.91 & 68.75 & 75 & 100 & 100 & 66.66 & 50 & 100 & 87.5 & 88.89 & 50 & 100 \\
\hline Chironomidae (larvae) & 90.91 & 68.75 & 75 & 100 & 100 & 66.66 & 50 & 100 & 87.5 & 88.89 & 50 & 100 \\
\hline Chironomidae (pupae) & 0 & 0 & 0 & 12.5 & 11.11 & 16.67 & 0 & 0 & 0 & 0 & 0 & 0 \\
\hline Hymenoptera* & 27.27 & 12.5 & 0 & 0 & 0 & 0 & 0 & 0 & 0 & 11.11 & 0 & 0 \\
\hline Formicidae* & 27.27 & 12.5 & 0 & 0 & 0 & 0 & 0 & 0 & 0 & 0 & 0 & 0 \\
\hline Vespidae* & 0 & 0 & 0 & 0 & 0 & 0 & 0 & 0 & 0 & 11.11 & 0 & 0 \\
\hline Ephemeroptera (nymph) & 0 & 12.5 & 0 & 37.5 & 55.56 & 33.33 & 0 & 0 & 0 & 0 & 0 & 0 \\
\hline Ephemeroptera (larvae) & 0 & 0 & 0 & 0 & 0 & 0 & 0 & 0 & 12.5 & 0 & 0 & 0 \\
\hline Odonata (nymph) & 0 & 0 & 0 & 0 & 11.11 & 16.67 & 0 & 0 & 0 & 11.11 & 0 & 0 \\
\hline Trichoptera & 0 & 0 & 0 & 25 & 22.22 & 33.33 & 0 & 0 & 12.5 & 77.78 & 50 & 100 \\
\hline Lepidoptera (larvae)* & 0 & 0 & 0 & 0 & 11.11 & 0 & 0 & 0 & 0 & 0 & 0 & 0 \\
\hline Insect parts & 63.64 & 50 & 25 & 75 & 88.89 & 50 & 0 & 33.33 & 75 & 33.33 & 25 & 0 \\
\hline Aracnida & 0 & 0 & 0 & 25 & 22.22 & 0 & 0 & 0 & 0 & 11.11 & 0 & 0 \\
\hline Acarina & 0 & 0 & 0 & 25 & 22.22 & 0 & 0 & 0 & 0 & 11.11 & 0 & 0 \\
\hline Organic Material & 100 & 100 & 100 & 100 & 100 & 100 & 100 & 100 & 100 & 100 & 100 & 100 \\
\hline Plant Material & 81.82 & 56.25 & 50 & 87.5 & 66.67 & 100 & 50 & 33.33 & 75 & 100 & 50 & 100 \\
\hline Sediment & 9.09 & 18.75 & 75 & 37.5 & 55.56 & 66.67 & 50 & 100 & 50 & 44.44 & 75 & 100 \\
\hline $\mathrm{n}$ & 11 & 16 & 4 & 8 & 9 & 6 & 2 & 3 & 8 & 9 & 4 & 2 \\
\hline
\end{tabular}

Mean values of the repletion index (RI) rose during the months of August and October 2002 and March 2003 for males, and during early October 2002 and late December 2002 for females (Fig. 2). The hepatosomatic index (HsI) showed a
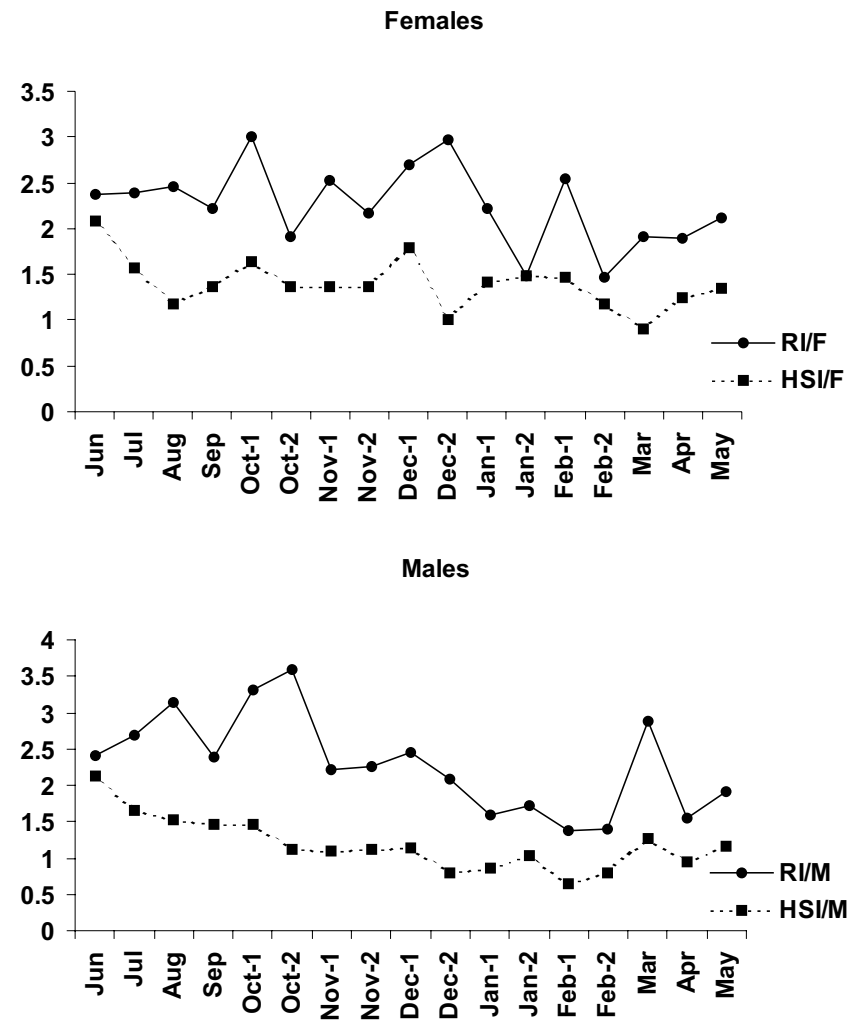

Fig. 2. Monthly distribution of the repletion (RI) and hepatosomatic indexes (HsI) average values of Eigenmannia trilineata males and females. similar distribution to the RI both in males and females, with higher values in June 2002 for both sexes (Fig. 2). The correlation between these two indexes was positive and significant in males $(\mathrm{r}=0.76$ and $\mathrm{p}=0.0004)$ and non-significant in females $(\mathrm{r}=0.3624$ and $\mathrm{p}=0.1529)$.

Monthly data for rainfall, photoperiod and temperature are summarized in Table 5. A significant dependence on these values related to RI of males $(\mathrm{F}=1.137 ; 1.092 ; 1.683)$ and females $(\mathrm{F}=0.621 ; 0.679 ; 0.488)$ was not verified according to the analysis of variance (Anova) of multiple regression.

The distribution of the average values of the condition factor $(\mathrm{CF})$ was similar in males and females. For males the higher value occurred in September 2002 and late January, March and May 2003. For females the period of greater elevation occurred from June to August and late November 2002, and January 2003 (Fig. 3). The variation of the condition factor without the gonad weight (CF1) and without the gonad and stomach weight (CF2) presented the same variation tendency of the initial condition factor, but with lower values (Fig. 3).

The difference in the analysis between CF- CF1 $(\Delta \mathrm{CF} 1)$ and CF- CF2 ( $\triangle \mathrm{CF} 2)$ showed the period of influence of each organ in the condition factor. The $\Delta \mathrm{CF} 1$ variation indicated that gonad growth influenced the condition factor primarily in November 2002 for males (Fig. 4). The influence of gonadal developoment is more evident in females than in males, increasing from early October 2002 to late February 2003. The differences between CF1 - CF2 ( $\triangle \mathrm{CF} 2$ ) were greater from June 2002 to late October 2002 for males and in the months of June and July 2002 for females when their stomachs were fuller (Fig. 4).

The E. trilineata intestinal quotient was estimated as 0.29 , with standard deviation of 0.019 and without variation during the months of the year. 
Table 3. Index of alimentary importance for $E$. trilineata adult food categories. Bold numbers = main item; framed numbers $=$ addition item; simple numbers $=$ accidental item.

\begin{tabular}{lccccc|c|c|c|c|c|c|c|c|}
\hline Items & Jun & Jul & Aug & \multicolumn{1}{c}{ Sep } & \multicolumn{1}{c}{ Oct } & \multicolumn{1}{c}{ Nov } & \multicolumn{1}{c}{ Dec } & \multicolumn{1}{c}{ Jan } & \multicolumn{1}{c}{ Feb } & Mar & Apr & May \\
\hline Microcr & $\mathbf{0 . 4 3}$ & $\mathbf{0 . 3 6}$ & $\mathbf{0 . 4 3}$ & $\mathbf{0 . 4 4}$ & $\mathbf{0 . 3 2}$ & \multicolumn{2}{c}{0.28} & 0.27 & 0.25 & 0.25 & 0.27 & $\mathbf{0 . 3 3}$ & $\mathbf{0 . 4 3}$ \\
DOM & $\mathbf{0 . 4 5}$ & $\mathbf{0 . 4 8}$ & $\mathbf{0 . 5 5}$ & $\mathbf{0 . 4 4}$ & $\mathbf{0 . 4 9}$ & \multicolumn{1}{|c|}{$\mathbf{0 . 5 3}$} & $\mathbf{0 . 6}$ & $\mathbf{0 . 6}$ & $\mathbf{0 . 5}$ & $\mathbf{0 . 4 8}$ & $\mathbf{0 . 4 6}$ & $\mathbf{0 . 4}$ \\
PM & $\mathbf{0 . 3 8}$ & 0.24 & 0.22 & 0.19 & 0.22 & 0.23 & 0.26 & 0.23 & 0.27 & 0.24 & 0.23 & 0.24 \\
AuI & 0.22 & $\mathbf{0 . 4 4}$ & 0.3 & $\mathbf{0 . 4 9}$ & $\mathbf{0 . 4 8}$ & $\mathbf{0 . 4 9}$ & $\mathbf{0 . 4 2}$ & 0.29 & $\mathbf{0 . 3 6}$ & $\mathbf{0 . 5 6}$ & $\mathbf{0 . 4 4}$ & $\mathbf{0 . 4 3}$ \\
AlI & 0.09 & 0.08 & 0.03 & 0.04 & 0.02 & 0.03 & 0.07 & 0.07 & 0.05 & 0.06 & 0.05 & 0.05 \\
Sed & 0.06 & 0.1 & 0.11 & 0.13 & 0.14 & 0.21 & 0.24 & 0.23 & 0.23 & 0.23 & 0.23 & 0.23 \\
Arac & 0 & 0 & 0.05 & 0.06 & 0.13 & 0.08 & 0.09 & 0.11 & 0.07 & 0.07 & 0.04 & 0.09 \\
Other & 0.06 & 0.02 & 0 & 0 & 0.01 & 0.03 & 0.02 & 0.07 & 0.02 & 0 & 0 & 0 \\
\hline
\end{tabular}

Table 4. Index of alimentary importance for $E$. trilineata juvenile food categories. Bold numbers = main item; framed numbers $=$ addition item; simple numbers $=$ accidental item.

\begin{tabular}{|c|c|c|c|c|c|c|c|c|c|c|c|c|}
\hline Items & Jun & Jul & Aug & Sep & Oct & Nov & Dec & Jan & Feb & Mar & Apr & May \\
\hline Microcr & 0.64 & 0.55 & 0.38 & 0.54 & 0.45 & 0.46 & 0.38 & 0.33 & 0.51 & 0.45 & 0.56 & 0.5 \\
\hline DOM & 0.43 & 0.49 & 0.56 & 0.44 & 0.45 & 0.54 & 0.5 & 0.5 & 0.51 & 0.5 & 0.38 & 0.38 \\
\hline PM & 0.21 & 0.16 & 0.13 & 0.22 & 0.17 & 0.25 & 0.13 & 0.08 & 0.19 & 0.25 & 0.13 & 0.25 \\
\hline $\mathrm{AuI}$ & 0.27 & 0.22 & 0.19 & 0.35 & 0.39 & 0.33 & 0.13 & 0.33 & 0.29 & 0.33 & 0.31 & 0.38 \\
\hline AlI & 0.07 & 0.03 & 0 & 0 & 0.03 & 0 & 0 & 0 & 0 & 0.03 & 0 & 0 \\
\hline Sed & 0.02 & 0.05 & 0.19 & 0.1 & 0.14 & 0.17 & 0.13 & 0.25 & 0.04 & 0.11 & 0.19 & 0.25 \\
\hline Arac & 0 & 0 & 0 & 0.06 & 0.06 & 0 & 0 & 0 & 0 & 0.03 & 0 & 0 \\
\hline Other & 0 & 0 & 0 & 0 & 0 & 0 & 0 & 0 & 0 & 0 & 0 & 0 \\
\hline
\end{tabular}

\section{Discussion}

Observing the mean value variation of the repletion index (RI) from E. trilineata along the study period, we conclude that males reduce their feeding activity during the months that reproduction occurs. A peak in the RI in October, corre-
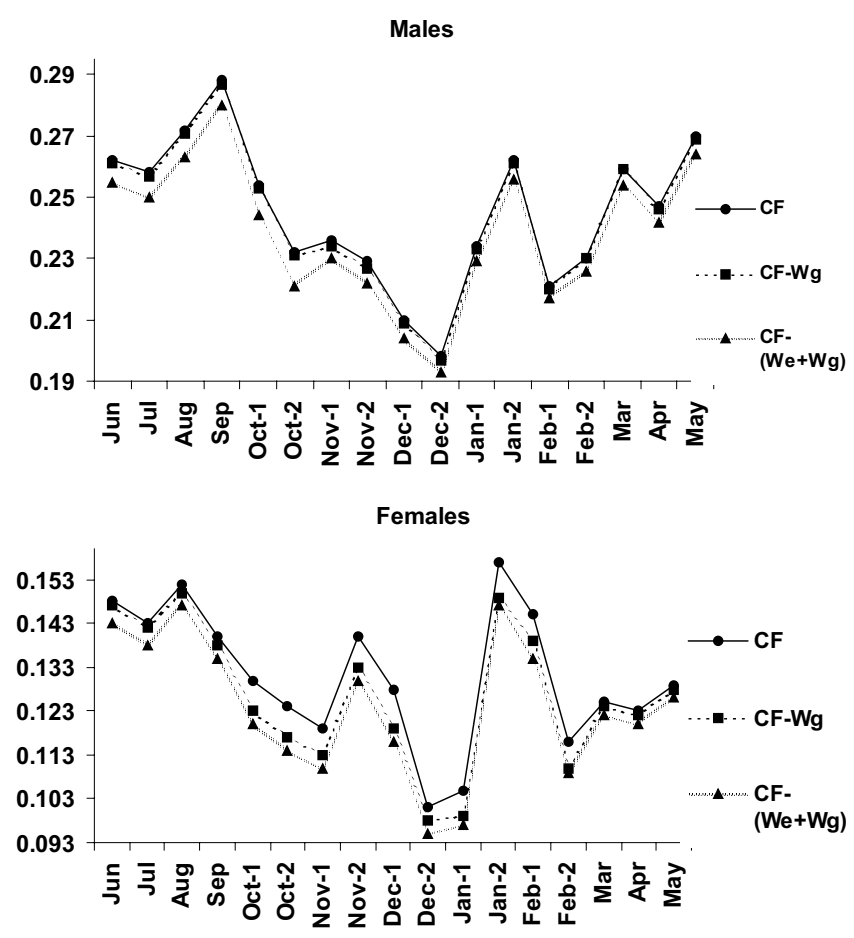

Fig. 3. Monthly distribution of the condition factor (CF) average, condition factor without the gonad weight (CF1) and condition factor without the gonad and stomach weight (CF2) in males and females of Eigenmannia trilineata. sponds to the beginning of the reproductive period and another peak in March, corresponds to when the reproductive period finishes. This pattern is not seen in females. Instead for females we observed successive peaks and falls in the RI values during reproductive period. These results can be explained by the probable parental care, since larval aggregation with one adult male were found under vegetation between December 2002 and March 2003. Crampton \& Hopkins (2005) observed in Gymnotus species in the Amazon basin that these larval nest aggregations are protected by an adult male until they reach certain size and disperse. Females do not present this behavior and they can continue their feeding activity, which could be increased by habitat displacement to search for reproductive partners. Barbieri \& Barbieri (1984) calculated RI to grouped males and females of Gymnotus carapo of the Lobo dam in São Paulo and found the lowest values of RI along the reproductive period.

Significant positive correlation was obtained between the RI and HsI to males and suggested energy storage in their liver. Females, however, did not present a significant correlation between these indexes because they use metabolic reserves from the liver in the formation of gonadal products (Jobling, 1995), and this is the probable cause of falling HsI values observed before the reproductive period (October to February).

Southern Brazil presents subtropical climate, and numerous studies of this region (Azevedo et al., 2000; Oliveira, 2003; Lampert, 2003) have shown association between fishes reproductive seasonality and activity and the photoperiod. Nevertheless, this tendency was not observed in the studied population, where the RI demonstrated no significant dependence with the abiotic factors.

Predominance of DOM in the stomachs was verified through the three methods of analysis for both adults and juveniles. This result can be explained by the fact that the 
Table 5. Monthly variation of the rainfall $(\mathrm{mm})$, water temperature $\left({ }^{\circ} \mathrm{C}\right)$ and photoperiod values in Lagoa Negra.

\begin{tabular}{cccc}
\hline & Rainfall & Photoperiod & Temperature \\
\hline Jun & 178.8 & 613 & 13.3 \\
Jul & 186.6 & 629 & 14.6 \\
Aug & 154.3 & 682 & 25.2 \\
Sep & 167.8 & 733 & 18.3 \\
Oct & 177.5 & 786 & 20.7 \\
Nov & 117.5 & 826 & 20.7 \\
Dec & 137.2 & 865 & 23.4 \\
Jan & 130.9 & 826 & 25.3 \\
Feb & 199.2 & 783 & 25.5 \\
Mar & 108.2 & 732 & 22.2 \\
Apr & 88.9 & 679 & 19.9 \\
May & 46 & 637 & 18.7 \\
\hline
\end{tabular}

genus Eigenmannia exhibits crepuscular habit (Mago-Leccia, 1994) and because collections were made between 11:00 a.m. and 12:30 p.m. Therefore, when the specimens were preserved, most of the ingested food was partially or totally digested.

Microcrustacea was an extremely frequent category in the diet of juveniles and adults of E. trilineata. In adults, however, Microcrustacea was classified as additional food source between November 2002 and March 2003. In juveniles it was the main food item in all months of the year. Diet shift in adults occurs in the reproductive period and suggests that they are perhaps searching for energy-rich food sources in this period, thus spending less energy in the foraging activity. Fish diet can vary with the season, prey abundance, activity, changes in the biotope and with the distribution of other fish species (Lowe-McConnell, 1999).

$\mathrm{PM}$ and Sed were highly frequent during all months. These categories were considered additional and accidental food items along the studied period (except July, when adults fed off PM as main aliment). These high frequencies can be explained by the fact of this species feeds at the bottom or under floating vegetation and the most part of the diet items live close to the plant roots. Ephemeroptera nymphs and Trichoptera larvae have their development at the bottom (Carrera, 1973) and Chironomidae larvae lives in agglomerations in the floating plant roots. Thus, PM (basically roots) and Sed (silex grains) found in E. trilineata stomachs could have been ingested accidentally while the fishes were ingesting another aliment.

The fact that the categories Arac, AlI and Other present higher frequency of occurrence in adults, and the observation of the existence of a much higher number of ingested alimentary items in adults related to juveniles corroborate Wooton (1984), who suggests that foraging is selective during the larval and juvenile development - mostly because mouth size and locomotion ability limit the ingestion of larger items.

E. trilineata is evidently an omnivore with an insectivorous tendency. This agrees with feeding analysis of Sternopygidae undertaken by other authors. Mérigoux \& Ponton (1998) identified insect larvae and microcrustaceans as food items of Sternopygus macrurus (Bloch \& Schneider, 1801) from French Guiana. Soares (1979) quoted Chironomidae
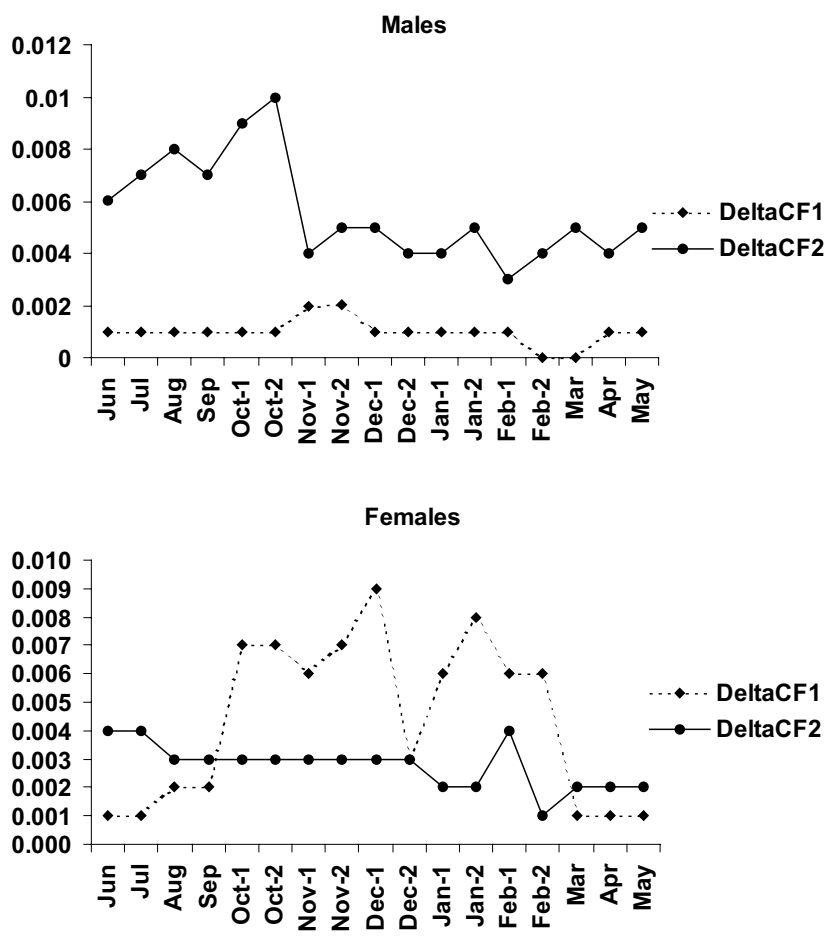

Fig. 4. Monthly variation of the $\triangle \mathrm{CF} 1$ and $\triangle \mathrm{CF} 2$ values in males and females of Eigenmannia trilineata.

larvae, Coleoptera larvae, Trichoptera and Ephemeroptera naiad as main components of Amazon basin E. virescens (Valenciennes, 1842) diet.

From the food item analysis of the studied population it can also be suggested that this population feeds in several water column levels, ingesting prey at the bottom (e.g. Ephemeroptera nymphs and Trichoptera larvae), in the floating vegetation roots (e.g. Chironomidae larvae), free swimmers (e.g. Microcrustacea) and allochthonous origin insects, which fall in the water (e.g. Hymenoptera). Alves-Gomes (1997) made similar observation for Eigenmannia sp. collected in Roraima, founding allochthonous insect parts, some larvae, planktonic crustaceans and quartz grain in its stomachs suggesting feeding in diverse microhabitats.

The condition factor has been extensively used in mathematics models applied to fishing biology and as a parameter of the fish general state (Barbieri \& Verani, 1987). Because this parameter is related to the fish physiological state, it can change in agreement with the fat quantity, environmental conditions, food supply and levels of parasitism.

For E. trilineata, the biggest discrepancy between condition factor and condition factor without gonad weight occurred during the reproductive period. This is more evident in females due to the larger volume of the ovaries comparatively to the testis.

These data exemplify how a species condition factor can be used as a good indicator of the spawning period. This fact was also demonstrated by Vazzoler \& Vazzoler (1965) for Sardinella aurita and by Barbieri \& Verani (1987) for 
Hypostomus aff. plecostomus. Barbieri \& Barbieri (1984) found similar results for G. carapo, where ovaries showed a great influence on the condition factor during the reproductive period than testes. This result is expected since the male gonads are relatively smaller than those of the female. However, the stomach weight influence in this factor is much more evident in males, where the biggest differences between CF1CF2 occurred in the months before the reproduction season.

The intestine length is clearly related to the species trophic category, arranged as: carnivorous $<$ omnivorous $<$ herbivorous $<$ detritivorous (Fryer \& Iles, 1972). Therefore, the low value estimated for the E. trilineata intestinal quotient agrees with the largely omnivorous feeding habit defined for the species.

\section{Acknowledgments}

We are grateful to William Crampton and Luiz R. Malabarba for comments on the manuscript and to colleagues of the Laboratório de Ictiologia for their help during field work. To Capes for the scholarships given to senior author, and $\mathrm{CNPq}$ for financial support (proc. 464545/00-5;476821/2003-7).

\section{Literature Cited}

Agostinho, A. A., J. D. Latine, K. D. G. da Luz \& L. C. Gomes. 2003. A ictiofauna do rio das Antas, área de influência do Complexo Energético do Rio das Antas. Maringá, Limnobio, $203 \mathrm{p}$.

Albert, J. S. 2001. Species diversity and phylogenetic systematics of American knifefishes (Gymnotiformes, Teleostei). Miscellaneous Publishing of Museum Zoology University of Michigan, 190:1-129.

Albert, J. S. 2003. Family Sternopygidae. Pp. 487-491. In: Reis, R. E., S. O. Kullander \& C. J. Ferraris, Jr. 2003. Check list of the freshwater fishes of south and central américa. Porto Alegre, Edipucrs, 742p.

Alves-Gomes, J. A. 1997. Informações preliminares sobre a bio-ecologia de peixes elétricos (Ordem Gymnotiformes) em Roraima. Pp. 509-555. In: Barbosa, R. I., E. J. G. Ferreira \& E. G. Castellón (Eds.). Homem, Ambiente e Ecologia no Estado de Roraima. Manaus, INPA, 613p.

Azevedo, M. A., L. R. Malabarba \& C. B. Fialho. 2000. Reproductive biology of the inseminated Glandulocaudine Diapoma speculiferum Cope (Actinopterygii: Characidae). Copeia, 2000(4): 983-989.

Barbieri, G. \& M. C. Barbieri. 1984. Note on nutricional dynamics of Gymnotus carapo (L.) from the Lobo Reservoir, São Paulo State, Brasil. Journal of Fish Biology, 24: 351-355.

Barbieri, G. \& J. R. Verani. 1987. O fator de condição como indicador do período de desova em Hypostomus aff. plecostomus (Linnaeus, 1758) (Osteichthyes, Loricaridae), na represa do Monjolinho (São Carlos, SP). Ciência e Cultura, 39(7): 655-658.

Carerra, M. 1973. Entomologia para você. São Paulo, Edart, 185p.
Crampton, W. G. R. 1998. Electric signal design and habitat preferences in a species rich assemblage of Gymnotiform fishes from the upper Amazon basin. Anais da Academia Brasileira de Ciências, 70(4): 805-847.

Crampton, W.G.R., Hopkins, C.D. 2005. Nesting and paternal care in the weakly electric fish Gymnotus (Gymnotiformes: Gymnotidae) with descriptions of larval and adult electric organ discharges of two species. Copéia, 2005(1).

Fryer, G. \& T. D. Iles. 1972. The cichlid fishes of the great lakes of Africa. Edimburg, Oliver \& Boyd, 230p.

Granado-Lorencio C. \& F. Garcia-Novo. 1986. Feeding habits of the fish community in a eutrophic reservoir in Spain. Ekologia Polska, 34(1): 95-110.

Guillen, E. \& C. Granado. 1984. Alimentacion de la ictiofauna del embalse de Torrejon (rio Tajo, Caceres). Limnética, 1:304-310.

Hahn, N. S., R. Fugi, V. L. L. Almeida, M. R. Russo \& V. E. Loureiro. 1997. Dieta e atividade alimentar de peixes do reservatório de Segredo. Pp. 141-162. In: Agostinho A. A. \& L. C. Gomes (Eds.). Reservatório de Segredo - bases ecológicas para o manejo. Maringá, Eduem, 387p.

Hynes, H. B. N. 1950. The food of freshwater sticklebacks (Gasterosteus aculeatus an Pygosteus pungitius), a review of methods used in studies of the food fishes. Journal of Animal Ecology, 19: 36-57

Hyslop, E. J. 1980. Stomach contents analisys; a review of methods and their application. Journal of Fish Biology, 17: 411-429.

Jobling, M. 1995. Environmental biology of fishes. London, Chapman \& Hall, 455 p.

Lampert, V. R. 2003. Biologia reprodutiva de duas espécies do gênero Bryconamericus (Characidae: Tetragonopterinae) dos sistemas dos rios Jacuí e Uruguai, RS. Dissertação de Mestrado Não Publicada, Universidade Federal do Rio Grande do Sul, Porto Alegre. 73p.

Lowe-McConnell R. H. 1999. Estudos ecológicos de comunidades de peixes tropicais. São Paulo, Edusp, 553p.

Mago-Leccia, F. 1976. Venezuelan gymnotiform fishes: a preliminary study for a revision of the group in South America. Ph.D. diss. Universidade Central de Venezuela.

Mago-Leccia, F. 1994. Electric fishes of the continental waters of América. Cracas, Clemente editores, $207 \mathrm{p}$.

Mérigoux, S. \& D. Ponton. 1998. Body shape, diet and ontogenetic diet shifts in young fish of the Sinnamary River, french Guiana, South América. Journal of Fish Biology, 52:556-569.

Nakatani, K., A. A. Agostinho, G. Baumgartner, A. Bialezki, P. V. Sanches, M. C. Makrakis \& C. S. Pavanelli. 2001. Ovos e larvas de peixes de água doce - Desenvolvimento e manual de identificação. Maringá, Eduem, 378p.

Oliveira, C. L. C. 2003. Análise comparada de caracteres reprodutivos e da glândula branquial de duas espécies de Cheirodontinae (Teleostei: Characidae). Dissertação de Mestrado Não Publicada, Universidade Federal do Rio Grande do Sul, Porto Alegre. 80p.

Santos, E. P. dos. 1978. Dinâmica de poupulações aplicada à pesca e piscicultura. Sâo Paulo, Edusp, 129p. 
Soares, M. G. M. 1979. aspectos ecológicos (alimentação e reprodução dos peixes do igarapé do Porto, Aripuanã, MT. Acta Amazônica, 9(2): 325-352.

Vazzoler, A. E. A. de M., \& Vazzoler, G. 1965. Relation between condition factor and sexual development in Sardinella aurita (Cuv. \& Val. 1847). Anais da Academia Brasileira de Ciências, 37: 353-359.

Wootton, R. J. 1984. Introduction: tactics and strategies in fish reproduction. Pp.1-12. In: Potts, G. W. \& M. N. Wootton (Eds.) Fish reproduction: strategies and tatics. London, Academic Press, 410p.

Zar, J. H. 1999. Biostatistical analisis. New Jersey, PrenticeHall, 663p.

Received March 2005

Accepted June 2005 